\title{
ЛЕКСИКА ХОРВАТСКОГО СЛАВОНСКОГО ГОВОРА В СОПОСТАВИТЕЛЬНОМ АСПЕКТЕ ${ }^{1}$
}

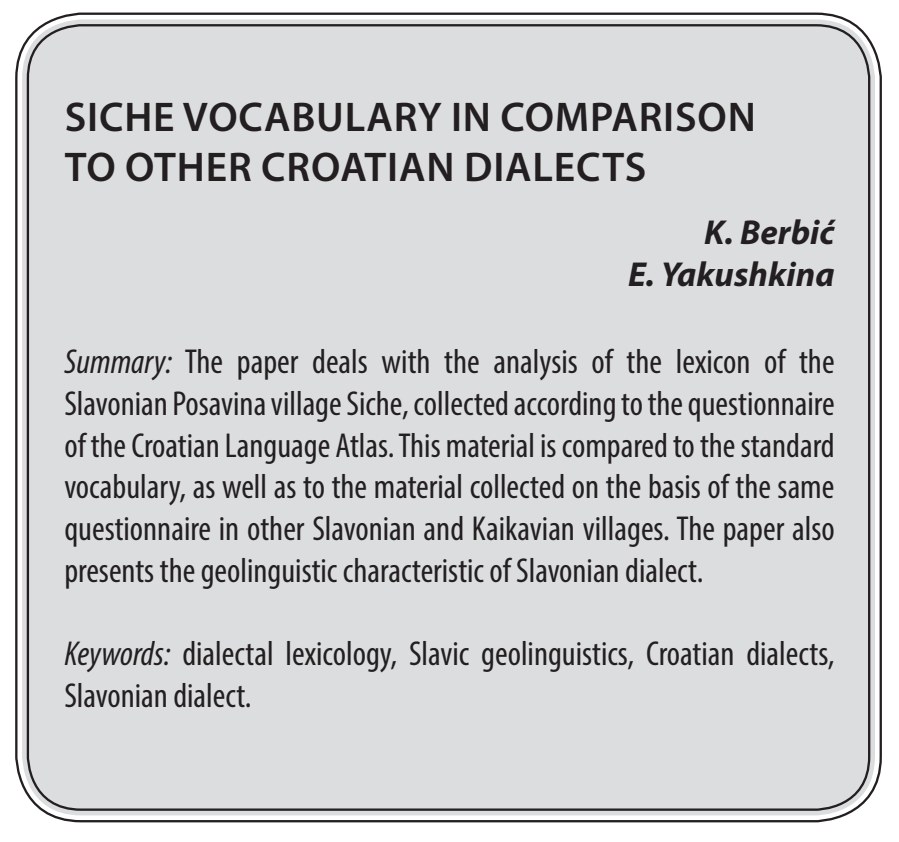

\section{Введение}

Предметом исследования в настоящей работе является лексическое своеобразие говора хорватского села Сиче, расположенного в долине реки Сава в 40 км к западу от г. Славонски Брод. Данная работа является частью комплексного исследования лексических связей и противопоставлений говоров хорватского языка и шире - центральноюжнославянской диасистемы. Исследование проводится в условиях отсутствия хорватского диалектного атласа и поэтому основывается в своих выводах на специально собранном для этой цели полевом материале. Задача данной статьи - выявить общенародную хорватскую составляющую и дифференциальную часть в лексике одного из славонских говоров, а также проследить лексические связи села Сиче с соседними говорами.

Говор относится к славонскому диалекту штокавского наречия - одного из трех наречий хорватского языка (наряду с чакавским и кайкавским). Штокавское наречие представляет собой совокупность так называемых старо- и новоштокавских говоров. Славонские говоры относятся к первому, архаическому типу, а в основе хорватского литературного языка лежат говоры второго, инновационного типа, а именно восточногерцеговинские.
Бербич Колар Эмина

Д.филол.н., профессор, Университет им. Й.Ю. Штроссмайера в Осиеке ebkolar@gmail.com

якушкина Екатерина Ивановна

К.филол.н., дочент, Московский государственный университет им. М.В. Ломоносова,

jkatia@yandex.ru

Аннотация: Настоящая статья посвящена анализу лексического материала, записанного в славонском посавском селе Сиче по вопроснику Хорватского лингвистического атласа. В статье представлены результаты сопоставления лексики из Сиче с литературной хорватской лексикой, а также выделяются лексемы, противопоставляющие говор Сиче другим исследованным славонским говорам и кайкавскому говору села Доня-Пачетина. Лексические связи сичанского говора с другими говорами региона демонстрируются на примере карт «0бщеславянского лингвистического атласа».

Ключевые слова: диалектная лексикология; славянская лингвогеография; хорватские диалекты; славонский диалект.

Во внутренней класификации славонского диалекта говор с. Сиче относится к посавским говорам. Говор архаичен, что выражается в ряде фонетических и морфологических черт: сохранение акута и старого места ударения (в восточногерцеговинском диалекте акут отсутствует и ударение перенесено на один слог к началу слова), сохранение / в конце слога, которое в восточногерцеговинском диалекте перешло в о (položil, при хорв. литер. položio), сохранение групп jt (dojt при литер. doći), jd (dojde при литер. dođe), сохранение старых окончаний (более близких к праславянской форме, чем в восточногерцеговинском диалекте) в склонении множественного числа имен существительных. Говор живой, используется молодым поколением, однако в связи с тем, что число жителей села падает (согласно последней переписи, в селе проживает 306 человек), его можно считать исчезающим. Вследствие своей редкой архаичности говор включен Министерством культуры Хорватии в список хорватских говоров, относящихся к национальному достоянию.

В основе исследования лежит ограниченный, но содержащий базовую лексику корпус - около 500 сичанских лексем, относящихся к 14 тематическим группам: Человек и части тела, Семья, Одежда, Дом, Еда и приготовление пищи, Земледелие и переработка зерна, До-

1 Исследование выполнено при финансовой поддержке РФФИ в рамках научного проекта № 19-012-00471. 
машние животные, Птицы, Дикие животные, Деревья и фрукты, Овощи и иветы, Ремесла, Природа, Общественная жизнь. Материал был записан в селе Сиче в ноябре 2019 г. по анкете, составленной на основе лексических вопросов вопросника «Хорватского лингвистического атласа»². Материалы анкеты в полном объеме опубликованы в работе [Бербич Колар, Якушкина, 2020]. Полученный корпус был дополнен анкетами, записанными от носителей говоров сел Нови Град 3 и Клокочевци ${ }^{4}$, также находящихся на территории распространения славонского диалекта5

Лексика с. Сиче лексикографически описана в словаре Э. Бербич Колар и Л.Коленич, насчитывающем 6 тыс. слов [Berbić Kolar, Kolenić, 2014]. В предваряющем словарь описании говора содержится характеристика сичанской лексики, где выделяются наиболее для нее значимые терминологические группы, такие как устройство дома, земледелие, рыбная ловля, резьба по дереву и др. [Berbić Kolar, Kolenić, 2014, s. 87-91] ${ }^{6}$, а также отмечается большое количество заимствований и использование устаревшей и редкой лексики. В своем описании славонских говоров классик хорватской диалектологии Й. Лисац, кратко останавливаясь на своеобразии их лексики, также отмечает наличие в славонских говорах заимствований, архаизмов (litka 'голень') и диалектизмов (oplećak 'короткая женская рубаха', pokrovac 'покрывало', lanac'единица измерения земли') [Lisac, 2003, s. 38].

\section{Методология исследования}

Чтобы вписать лексику говора, являющегося основным предметом исследования, в более широкий лингвогеографический контекст и определить, пусть и упрощенно, место говора в центральноюжнославянском диалектном континууме, мы привлекаем к сопоставлению материалы и карты «Общеславянского лингвистического атласа».

Далее для выявления лексической специфики хорватского говора мы обращаемся к сравнению лексики, представленной в анкете из данного села, с лексикой хорватского литературного языка, засвидетельствованной в словаре Hrvatski jezični portal (http://hjp.znanje.hr/).
Такое сравнение применяется нами для того, чтобы при описании анкет из разных пунктов, мы могли располагать показателем tertium comparationis и тем самым удобнее сопоставлять лексические типы разных говоров. Этот показатель демонстрирует степень близости (удаленности) говора от общехорватского словарного фонда, и с его помощью можно сравнивать говоры, принадлежащие к разным диалектам и наречиям. Слова из дифференциальной части проверяются по диалектным словарям с целью выявления в говоре локальных слов и слов более широкого диалектного распространения.

Следующий этап анализа подразумевает описание лексического варьирования внутри одного диалекта и выделение его общих характерных признаков. Для этого сопоставляются анкеты говоров различных сел, относящихся к одному диалекту. На заключительном этапе анализа лексика рассматриваемого диалектного типа сопоставляется с лексикой говора или говоров, относящихся к иным диалектным типам, и выделяются изоглоссы, их противопоставляющие.

\section{Обшая ^ингвогеографическая характеристика славонской лексики}

В условиях отсутствия хорватского диалектного атласа основным источником по систематическому изучению географии хорватской лексики является «Общеславянский лигвистический атлас» (далее - ОЛА). Рассмотрим, в какие ареалы входит Славония по лексическим признакам, картографированным в ОЛА. Анализ производился преимущественно на основании лексики из тематической группы Человек и части тела, так как лексика именно этой рубрики использованного нами вопросника наиболее полно отражена в атласе [ОЛА, 2009]. Поскольку фонетические, морфологические и лексические изоглоссы на центральноюжнославянской территории, как правило, проходят с севера на юг, то гипотетически славонские говоры могут относиться к двум типам хорватских ареалов, западному и восточному. Подобная картина и имеет место в реальности: славонским говорам свойственно тяготеть к кайкавскому (кайкавско-чакавскому) ареалу или к основному массиву штокавских говоров ${ }^{7}$. Причем первое встречается реже, а второе

2 Список информантов из с. Сиче: Ana Ćupić (Grabrić) (1936 г.p.), Kristina Ćupić (1988 г.p), Stjepan Ćupić (1960 г.p.), Višnja Ćupić (Lulić) (1969 г.р.).

3 Информант - Igor llić (1997 г.р.).

4 Информант - Vjekoslava Kadić (1956 г.р.).

5 Кроме того, к сравнению привлекались анкеты, заполненные студентами педагогического факультета Университета им. Й. Ю. Штроссмайера в г. Славонски-Брод (из кайкавского села Доня-Пачетина, славонских сел Илача (восточная Славония), Врановци (центральная Посавина) и села Прекопакра в западной Славонии).

6 Наибольшее внимание при изучении славонской лексики уделяется именно исследованию тех или иных семантических групп традиционной славонской лексики [Bilić, 2012; Bockovac, 2014; Kolenić, Berbić Kolar, 2012 и др.].

7 Хорватский лингвист Д.Брозович полагал, что говоры сел Сиче и Магича Мала восходят к переходному кайкавско-западноштокавскому диалектному типу [Brozović, 1970, s. 17]. 
чаще. Проиллюстрируем это на нескольких примерах.

1. Кайкавско-чакавско-славонская общность. 1) Висок, боковая часть черепа от уха до кости лба [ОЛА, 2009, карта №4]. На хорватской территории присутствуют два основных названия виска: сложное слово slěроос̌(n)ica и словосочетание slěpo oko. В Славонии, согласно атласу, преимущественно распространена лексема slěроос̌ica, которая нами зафиксирована и в Сиче. Эта номинация объединяет славонские говоры с большинством кайкавских, некоторыми чакавскими и приморскими штокавскими говорами. Несколько упрощая ситуацию, границу между номинацией slěpoočica и slépo oko можно провести с северавостока на юго-запад, от г. Осиек к г. Трогир, отделяя большую часть говоров Хорватии от говоров Боснии. В с. Стризивойна, одном из более восточных славонских пунктов, в атласе зафиксировано slěpo oko. В полученных нами анкетных данных, кроме Сиче, везде фигурировало литературное слово sljepoočnica.

2) Рассказывает (сказку) [ОЛА, 2009, карта № 65]. В Сиче в этом значении записан глагол prepoviđat, причем он же выражает и значения 'говорить' и 'разговаривать'. Этот же глагол (pripovidati) характерен и для Нови-Град. В ОЛА он представлен в двух пунктах на территории Славонии (общ. Жупаня), а также в кайкавских, чакавских и приморских штокавских говорах. Второй глагол, который характерен для хорватских говоров - pričati, его ареал расположен к востоку от pripovědati. Граница ареалов этих лексем сходна с границей, отделяющей slěpoočica и slěpo oko. В Славонии pričati зафиксирован в соседнем с Сиче селе Магича- Мала и Стризивойна. Похожее ареальное противопоставление показывает распространение слов vlasi и kosa [ОЛА, 2009, карта № 25].

В наших записях из славонских сел встретилось и несколько других параллелей с кайкавскими и чакавскими говорами. В Клокочевци нам была предложена номинация list 'письмо', хотя в ОЛА на территории Славонии в этом значении записаны слова pismo и knjiga [ОЛА, 2003, карта №38]. В Нови-Град мы записали глагол тuс̌ati 'молчать', характерный для чакавских и кайкавских говоров и противопоставленный штокавскому глаголу šutjeti (ćutati).

2. Противопоставление славонских говоров кайкавским/ кайкавским и чакавским говорам.

1) Печень человека [ОЛА, 2009, карта № 54]. В хорватских говорах распространено два основных названия печени - jetra, представленное за пределами Хорватии также в словенских и чешских говорах, и crna džiger(ic)a. Слово jetra, согласно атласу, характерно для кайкавских и некоторых чакавских и приморских штокавских говоров, a crna džiger(ic)a употребляется в Славонии и Боснии и Герцеговине. В наших записях из Сиче также подтверждена лексема jetra, наряду с džigera.

2) Губы [ОЛА, 2009, карта № 17]. В хорватских говорах существуют три основные конкурирующие номинации губ: usne, usnice, gubice. Все они представлены на территории Славонии. Наш материал также отражает употребление в разных славонских говорах разных лексем, а именно gubice (Сиче) и usne (другие села). В атласе лексема gubice записана в с. Магича-Мала. Это слово связывает Сиче и Магича-Мала с говорами Боснии и Герцеговины, а в общеславянском масштабе - со словацкими и восточнославянскими говорами, для которых характерно обозначение типа *goby. Одновременнно данная номинация противопоставляет говор Сиче большей части говоров на территории Хорватии, в которых распространено название usne или usnice.

Похожее противопоставление славонских говоров более западным хорватским говорам, прежде всего кайкавским, а иногда и чакавским демонстрируют карты 'бросить камень', 'спина', 'усы', 'рот' [ОЛА, 2009], а также целый ряд других.

В заключение лингвогеографического экскурса рассмотрим карту Мизинеи [ОЛА, 2009, карта № 39], демонстрирующую своеобразие славонских говоров на общехорватском фоне. Практически на всей территории распространения хорватских говоров в ОЛА для мизинца зафиксировано наименование mali prst. Однако в Магича-Мала представлена также лексема zeko, записанная и в Сиче, а в Валпово - malčak, что корреспондирует с записанным в Клокочевци словом malčić. В других хорватских пунктах в ОЛА такие лексемы не засвидетельствованы.

\section{Отношение лексики села Сиче к лексике хорватского митературного языка}

В целях сопоставления сичанской лексики с общехорватским языком, материал анкеты был проверен по словарю хорватского литературного языка Hrvatskijezični portal. При этом фиксировались только лексические и словообразовательные отличия, фонетической вариативностью пренебрегалось (в том числе пренебрегалось и вариативностью основ в случаях bagra'акация', baza'бузина', zden 'холодный (о пище)'). Анализ показал, что 25\% лексем из списка отсутствуют в лексиконе хорватского литературного языка (в том числе присутствуют в ином значении или помечены как регионализмы, локализмы или этнографизмы). В ходе нашего дальнейшего исследования, когда подобные показатели будут определены и для других хорватских сел, можно будет оценить, насколько велика или мала полученная цифра. Однако уже 
сейчас можно предположить, что этот показатель достаточно высок. Такой вывод позволяет сделать сравнение с говором сербского села Господжинцы, расположенного к востоку от Славонии в области Воеводина. Отличия лексики этого говора от сербского литературного языка составляют 5\% (говор Господжинци относится к диалектному типу, лежащему в основе сербского литературного языка) [Якушкина, 2020а] ${ }^{8}$. Большинство сичанских слов, не принадлежащих к литературному языку, характерны для разных славонских говоров. Это показывают данные анкет из других славонских пунктов, а также данные словаря [Jakšić, 2015].

Рассмотрим сичанские лексемы, отличные от литературных хорватских, и проанализируем типологию этих отличий. Среди сичанской лексики, отсутствующей в словаре хорватского литературного языка или помеченной в нем в качестве региональной, локальной или употребляющейся под влиянием сербского языка, преобладают заимствования, а именно: турцизмы kičma 'позвоночник', с̌іс̌о 'дядя по отцу', babo 'отец', đerz 'жених, парень', marama 'платок', avlija 'двор', с́оร̌ak 'угол (дома),', 'угол в комнате', badža 'дымоход', sirće 'уксус', ekser 'гвоздь', раšаnас 'муж одной из сестер по отношению к мужу второй сестры', kajmak 'продукт, получаемый из слоя жира на кипяченом молоке', kajsija 'абрикос', testera 'пила', tarabe 'забор'; балканские грецизмы: talas 'волна', drum 'дорога', trpeza 'стол'; германизмы: grinzajg 'зелень', drukerić 'застежка', fertun 'фартук', froštuk'завтрак', paradajz 'помидор', čaira 'луг', špaga, štrik 'веревка', amper 'ведро для воды', žaga 'пила'; унгаризмы: vanjkuš 'подушка'; итальянизмы: zeko 'мизинец.9 Турцизмы и грецизмы объединяют славонские говоры с другими штокавскими говорами, ср., например, (avlija, ćošak, drum, ekser, marama, sirće, tarabe [Sekulić, 2005; Babić, 2008], kičma [Babić, 2008], то есть с востоком хорватского и шире цетральноюжнославянского ареала, что связано с историей штокавской территории, находившейся в составе Османской империи ${ }^{10}$. Германизмы и унгаризмы связывают Славонию с кайкавскими говорами, территория распространения которых, так же, как и Славония, входила в Габсбургскую империю, ср. кайкавские слова paradajz, špaga, žaga [Šatović, Kalinski, 2012], vankuš [Maresić, Miholek, 2011, s. 748].

Помимо заимствований, среди сичанской лексики, дифференциальной по отношению к литературному языку, выделяется несколько слов, которые противо- поставляют штокавские говоры (или большую их часть) кайкавским: točak 'колесо' (кайк. kotač), nedilja 'неделя' (кайк. tjeden), а также, напротив, - объединяют славонские говоры с кайкавскими: vlasi 'волосы на голове', svatovi 'свадьба', krt 'крот', poldana 'полдень'. Несколько лексем предположительно являются узко локальными: svaja 'сестра жены', svaj 'муж сестры', gudac 'пила', sjajna muva 'светлячок', kopanja 'деревяная посудина для замешивания теста'. Географию некоторых дифференциальных лексем пока нам определить не удалось: раšе 'хорошо, годится', lačinjak 'ремень', šetrica 'посуда для дойки', nakrižat 'разрезать', kominje 'стручок', natkrovak 'стреха', parovnjak 'ровесник, сверстник', prijaci 'родители мужа дочери, родители жены сына', starac 'тесть'.

\section{Вариашия внутри славонского корпуса}

Отличия в ответах, полученных в Сиче и соответственно в Нови-Град и Клокочевци, составляют примерно по $15 \%$. Однако в большинстве случаев эти различия связаны не с тем, что на одинаковые вопросы в качестве ответов получены разные диалектизмы: в одном селе получены в качестве ответа диалектизмы, а в другом слова, тождественные литературным, или в одном селе в качестве ответа было дано одно литературное слово, а в другом - другое. Например, в Нови-Град, в отличие от Сиче, записаны следующие слова (в скобках указаны сичанские лексемы): svadba (svatovi) 'свадьба', рunac (starac) 'тесть', žarač (širajz) 'инструмент для перемешивания топлива в печи', vani, napolju (na dvoru) 'на улице', plahta (ponjava) 'простыня', krtica (krt) 'крот', val (talas) 'волна', lokva (mlaka) 'лужа', kod kuće, kući (doma) 'дома, домой', dužina (duljina) 'длина', ključa(vrije) 'кипеть' и др.

Помимо турцизмов, для всех обследованных славонских сел характерны такие диалектизмы, как točak 'колесо' и расоv'крыса', связывающие славонские говоры с восточноштокавскими. На востоке Славонии появляется слово razboj 'ткацкий станок' (Врановци и Илача), также характерное для восточноштокавских говоров.

\section{Отношение славонской лексики к кайкавской}

Славонский диалект с запада граничит с кайкавским наречием и наиболее близок к нему из всех штокавских диалектов. В анкете из Доня-Пачетина по сравнению с материалами из Сиче представлено 25\% иной лексики. В отличие от противопоставлений внутри славонского

8 Поскольку показатель рассчитывался относительно разных словарей - хорватского и сербского, то, безусловно, полученные цифры не могут быть сопоставимы без оговорок. Нужно учитывать лексикографическую концепцию каждого словаря и различия в их объеме.

9 Этот список можно расширить за счет слов, записанных в Нови-Град (турцизмы: sinija'стол', makaze'ножницы', burma'обручальное кольцо', bаšс̌а' 'огород', duvar'стена'; унгаризмы: ара'отец', astal'стол'). Если учитывать сичанские слова, представленные и в литературном языке (например, pendžer'окно'), то список будет еще более обширным.

10 Славония входила в состав Османской империи с 1526 г. до конца XVII в. 
корпуса, которые, во многом, можно связывать с вариативностью внутри литературного языка, дифференциальные лексемы из Доня-Пачетина представляют собой, в основном, слова, не представленные в литературном языке.

Кайкавскую анкету от сичанской отличает бо́льшая архаичность представленной в ней лексики. Как мы отмечали выше, для славонских говоров характерно значительное число турцизмов и других балканизмов, тогда как в кайкавском говоре им соответствуют исконные славянские слова: plot 'забор', vugel 'угол', dvorište 'двор', dimljak'дымоход', momak 'парень', stol 'стол', bас̌va 'бочка', kožica 'продукт, получаемый из слоя жира на кипяченом молоке', pastir 'пастух', val 'волна', ručnik 'полотенце', sused 'сосед', pila 'пила', zastava 'флаг'. В числе архаизмов, вытесненных на востоке турцизмами, назовем и древние романские заимствования ocat 'уксус' и vrt'огород'.

Помимо распространения турцизмов, штокавские говоры на разных этапах своей истории развили много других лексических инноваций, в результате которых в них была утрачена общеславянская лексика. Кайкавские говоры не были затронуты этими инновациями, поэтому между говорами сел Доня-Пачетина и Сиче можно наблюдать следующие противопоставления (вначале приводится кайкавская лексема, а потом штокавская): zacjelivaju - ljubit 'целовать', željeze - gvožđe 'железо', ogenj - vatra 'огонь', objed - ručak 'обед', dažd - kiša'дождь', češnjak - bili luk 'чеснок', vugarek - krastavac 'огурец', luk - crveni luk'репчатый лук'.

Кайкавскому говору также свойственны инновации, но другого рода. Славонским турцизмам в кайкавской анкете соответствуют германизмы ${ }^{11}$ : štunfi носки', šogor 'муж одной из сестер по отношению к мужу второй сестры', cukar 'caхар', marelica 'абрикос', ciferšljus 'застежка', vura 'час'; унгаризмы: gumb 'пуговица', oblok 'окно'. Заимствованиям у кайкавцев часто соответствует исконная славянская лексика в славонских говорах: bažul 'фасоль' (славон. gra), gacija 'акация' (славон. bagra), trahtor 'во- ронка' (славон. livak), penazi 'деньги' (славон. novci), lojtra (славон. ljestve) 'лестница', kupica 'стакан' (славон. с̌аša), mustaći 'усы' (славон. brkovi), pohuti'жарить' (славон. рес́i).

Среди лексики, дифференцирующей говоры сел Доня-Пачетина и Сиче, есть много диалектизмов, выделявших кайкавские говоры по сравнению с более восточными, вероятно, еще в праславянскую эпоху: hiža 'дом', lačan 'голодный', tjedan 'неделя', ljete 'год', melja 'мука', trst 'виноградная лоза', hititi 'бросить', zelje 'капуста', djela 'paботать', deti 'положить', obljeka 'одежда', kokot 'петух'12.

\section{Выводы}

По территории славонских говоров проходят изоглоссы, объединяющие их как с кайкавскими, так и с прочими штокавскими говорами. С кайкавскими говорами, помимо общехорватских слов, славонскую лексику объединяют некоторые архаизмы (vlasi 'волосы', zipka 'колыбель', prositi 'просить', ljeto'год', željezo 'железо'), инновации (svatovi 'свадьба'), заимствования (širajz(lin) 'инструмент для перемешивания топлива в печи'). Со штокавскими говорами, в том числе с восточными, славонские говоры объединяются такими словами, как točak 'колесо', pacov'крыса', gvožđe 'железо', pečurka 'гриб'.

Большую роль в формировании лексического фонда славонских говоров играют турцизмы и другие балканизмы, которые также сближают славонские говоры с основным массивом штокавских и отдаляют их от кайкавских. Германизмов в нашем материале присутствует значительно меньше (ср. устойчивое в разных говорах širajzli, paradajz 'помидор', flaša 'бутылка', и подтвержденные анкетой из Прекопакры rajferšlus 'застежка', kinderbet 'колыбель').

Несмотря на архаичность фонетико-морфологической структуры славонских говоров, в анкетах из славонских сел нам встретилось ограниченное число лексических архаизмов: podojit, vlasi, zipka, prositi 'просить', okno (Сиче), baran, mučati, ljeto, strigati, rabota (НовиГрад), željezo (Клокочевци).

\section{ЛИТЕРАТУРА}

1. Бербич Колар Э., Якушкина Е. Диалектные материалы из Славонии. Stephanos №2 (40). 2020. С. 54-62.

2. Якушкина Е.И. Изоглоссы лексем праславянского происхождения в сербскохорватском ареале // Славяноведение. 2020 (в печати).

3. Якушкина Е.И. Сербская воеводинская лексика в сопоставительном и ареалогическом аспекте // Вестник славянских культур. 2020. (в печати). (Якушкина 2020а).

4. Berbić Kolar E.; Kolenić Lj. Sičanske riči. Osijek: Sveučilišta J.J.Strossmayera, 2014. 318 s.

5. Bilić A. Tradicijski leksik u Etnografskoj građii iz Retkovaca Ivana Filakovca // Tradicijski leksik: Šokačka rič 9, zbornik radova. Vinkovci: Zajednica kulturnoumjetničkih djelatnosti Vukovarsko-srijemske županije, 2012. S. 69-112.

11 Хорватская кайкавская территория с 1526 г. по 1918 г. находилась в составе Габсбургской (Австро-Венгерской) монархии. 
6. Bockovac T. Tradicijski leksik blagdana u Semartinu // Slavonski dijalekt i leksikografija: Šokačka rič 11. Vinkovci: Zajednica kulturno-umjetničkih djelatnosti Vukovarsko-srijemske županije, 2014. S. 231-244.

7. Brozović D. Dijalekatska slika hrvatsko-srpskog jezičkog prostora // Radovi Filozofskog fakulteta u Zadru, sv. 8. 1970. S. 5-32.

8. Kolenić Lj., Berbić Kolar E. Tradicijski sičanski leksik // Tradicijski leksik: Šokačka rič 9, zbornik radova. Vinkovci: Zajednica kulturno-umjetničkih djelatnosti Vukovarsko-srijemske županije, 2012. S. 7-42.

9. Lisac J. Hrvatska dijalektologija 1. Hrvatski dijalekti i govori štokavskoga narječja i hrvatski govori torlačkoga narječja. Zagreb: Golden marketing - Tehnička knjiga, 2003. $168 \mathrm{~s}$

10. Общеславянский лингвистический атлас. Серия лексико-словообразовательная. Вып. 8. Профессии и общественная жизнь. Warszawa, 2003. 192 c.

11. Общеславянский лингвистический атлас. Серия лексико-словообразовательная. Вып. 9. Человек. Kraków, 2009. 218 c.

12. Babić I. Studenački rječnik. Studenci: Župni ured Studenci, 2008. 553 s.

13. Jakšić M. Rječnik govora slavonskih, baranjskih i srijemskih. Zagreb: Dominović, 2015. 1050 s.

14. Maresić J., Miholek V. Opis i rječnik đurđevečkog govora. Đurđevac: Gradska knjižnica, 2011. 889 s.

15. Sekulić A. Rječnik govora bačkih Hrvata. Zagreb: Institut za hrvatski jezik i jezikoslovlje, Subotica: Katolički institut za kulturu, povijest i duhovnost Ivan Antunović, $2005.696 \mathrm{~s}$

16. Šatović F.; Kalinski I. Rječnik Cerja zagrebečkoga. Zagreb: Pučko otvoremo učiližte sv. Ivan Zelina, 2012. 628 s.

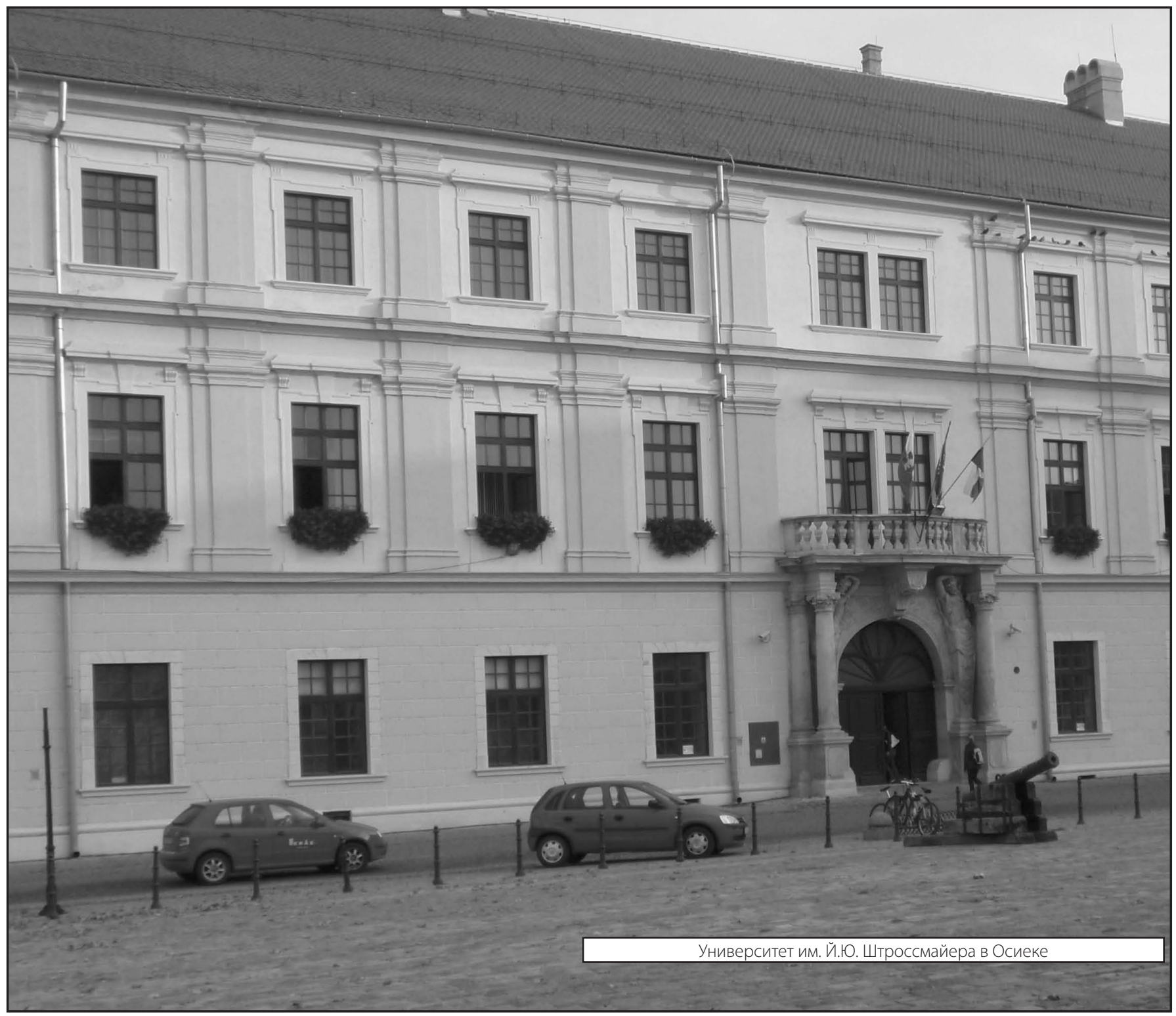

